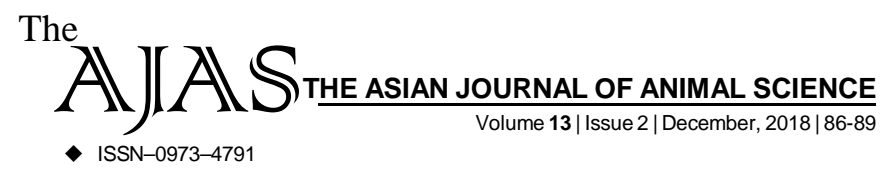

DOI : 10.15740/HAS/TAJAS/13.2/86-89 AA.

Visit us | www.researchjournal.co.in

RESEARCH ARTICLE.

\title{
Histological and histochemical studies on bulbourethral gland in prepubertal and pubertal ram
}

\section{P.J. Kapadnis and P.N. Thakur}

Author for Corresponding -

\section{P.N. Thakur}

Department of Veterinary Anatomy and Histology

College of Veterinary and Animal

Sciences, Parbhani (M.S.)

India
ABSTRACT...... Histologically, the bulbourethral gland consisted of capsule, interlobular septa, interstitial tissue, glandular alveoli and ducts, in prepubertal and pubertal ram. The glands were tubule alveolar consisting of serous and mucous alveoli duct. The serous alveoli were lined by simple columnar epithelium whereas mucous alveoli were lined by pyramidal shaped tall columnar epithelium. The interlobular duct was lined by pseudostratified epithelium.

KEY WORDS...... Histology, Histochemistry, Bulbourchthral gland, Prepubertal, Pubertal, Ram

HOW TO CITE THIS ARTICLE - Kapadnis, P.J. and Thakur, P.N. (2018). Histological and histochemical studies on bulbourethral gland in prepubertal and pubertal ram. Asian J. Animal Sci., 13(2): 86-89. DOI : 10.15740/HAS/TAJAS/13.2/86-89. Copyright@2018:HindAgri-Horticultural Society.

ARTICLE CHRONICLE - Received : 08.08.2018; Revised : 17.11.2018; Accepted : 27.11.2018 